\title{
ANALISIS KELAYAKAN USAHA ALAT TANGKAP GILLNET DI PERAIRAN SUNGSANG KABUPATEN BANYUASIN SUMATERA SELATAN
}

\author{
Natanael P. Siahaan, Riena F. Telussa \\ Universitas Satya Negara Indonesia \\ E-mail : natankoro@gmail.com
}

\section{PENDAHULUAN}

Secara umum, perikanan tangkap di Indonesia masih didominasi oleh usaha perikanan skala kecil. Menurut Hermawan (2005), hanya 15\% usaha perikanan di Indonesia merupakan usaha perikanan skala besar dan sisanya $(85 \%)$ adalah usaha perikanan skala kecil. Usaha perikanan yang ada di Kabupaten Banyuasin Sumatera Selatan, didominasi oleh usaha perikanan skala kecil.

Salah satu alat tangkap yang banyak digunakan oleh nelayan di Perairan Sungsang adalah gillnet. Secara umum gillnet dapat dibagi atas jaring dasar dan jaring permukaan. Sesuai dengan tujuan penangkapan ikan yang tertangkap untuk jaring dasar adalah jenis ikan demersal sedangkan untuk jaring permukaan ikan tertangkap adalah ikan pelagis Jenis alat tangkap yang umum dioperasikan di Kecamatan Banyuasin II Sungsang yaitu gillnet sebanyak 66 unit, sedangkan jumlah bagan tancap mencapai 460 unit. Hal ini menandakan jumah nelayan tradisional yang menggunakan gillnet kurang berkembang. Perkembangan alat tangkap gillnet juga dipengaruhi dengan jumlah investasi awal tergolong besar sehingga memberatkan nelayan untuk memulai usaha alat tangkap gillnet, karena di Sungsang belum terdapat bantuan pemerintah untuk nelayan. Selain itu faktor hasil tangkapan yang tidak menentu sehingga menyebabkan pendapatan nelayan yang tidak pasti juga mempengaruhi perkembangan jumlah nelayan alat tangkap gillnet tidak berkembang. Kebanyakan penduduk Sungsang lebih memilih bekerja ke luar daerah atau menjadi pekerja di bagan tancap yang memiliki penghasilan lebih pasti dibandingkan bila menjadi nelayan gillnet.

Sungsang merupakan satu-satunya perairan di Kabupaten Banyuasin wilayah Sumatera Selatan dengan mayoritas masyarakat mencari pendapatan dari hasil perikanan. Alat tangkap yang digunakan di perairan Sungsang didominasi oleh bagan tancap dengan hak kepemilikan perusahaan perikanan dan pengusaha besar. Sedangkan mayoritas nelayan di Sungsang didominasi dengan nelayan tradisional berupa alat tangkap gillnet. Hal inilah yang mendorong penulis untuk melakukan penelitian dengan judul "Analisis usaha alat tangkap gillnet di perairan Sungsang Kabupaten Banyuasin Sumatera Selatan" dengan harapan mengetahui apakah usaha alat tangkap gillnet di perairan Sungsang Kabupaten Banyuasin Sumatera Selatan layak untuk dilakukan dan dikembangkan. 


\section{MATERI DAN METODE}

Kegiatan Penelitian dilaksanakan pada bulan Juni 2017. Lokasi kegiatan ini dilaksanakan di Kabupaten Banyuasin, Sumatera Selatan dengan daerah penangkapan di perairan Sungsang.

Analisis R/C Ratio

Analisis imbangan penerimaan dan biaya ini bertujuan untuk mengetahui hasil yang diperoleh dari suatu kegiatan usaha dengan rumus (Hernanto, 1989):

Analisis ini digunakan untuk menentukan titik impas yang bertujuan untuk mengetahui sampai batas mana usaha yang dilakukan bisa memberikan keuntungan. Analisis titik impas ini menyatakan contoh jumlah tangkapan minimal yang harus diperoleh setiap tahun pada tingkat untung dan tidak rugi. Rumus yang digunakan adalah (Rahardi et al, 1993):

Payback Period adalah analisis pengembalian modal yang bertujuan untuk mengetahui berapa lama waktu yang diperlukan (dalam tahun atau bulan) untuk menutupi investasi dengan rumus (Hernanto, 1989):

Return On Investment (ROI) adalah analisis tingkat pengembalian investasi yang merupakan analisis usaha yang digunakan untuk mengetahui berapa prosentasi kemungkinan pengembalian keuntungan dari investasi yang ditanamkan dengan asumsi pendapatan setiap bulan atau tetap (Hernanto, 1989)..

Analisis ini bertujuan untuk mengetahui apakah suatu usaha layak untuk dikembangkan atau tidak. Menurut Djamin (1993) dalam menghitung analisis ini dapat digunakan analisis sebagai berikut:

NVP merupakan selisih antara Present Value dari benefit dan Present Value dari biaya. Benefit Cost of Ratio (BCR) merupakan perbandingan antara pendapatan kotor atau hasil penjualan dengan total biaya pemeliharaan

Tingkat investasi (IRR), adalah suatu tingkat bunga (dalam hal ini sama dengan discount rate) yang menunjukkan jumlah nilai sekarang netto (NPV) sama dengan jumlah seluruh ongkos investasi proyek. Untuk menentukan berapa tepatnya tingkat bunga yang ideal, caranya adalah dengan melakukan percobaan terus atau dengan menggunakan metode interpolasi/penyisipan di antara bunga yang lebih rendah (yang menghasilkan NPV positif) dengan tingkat bunga yang lebih tinggi (yang menghasilkan NPV negatif).

\section{METODOLOGI}

Metode yang digunakan dalam penelitian ini adalah metode survey melalui pengamatan langsung ke lapangan. Data primer dikumpulkan dari responden dengan menggunakan kuisioner yang telah terpola, sedangkan data sekunder dari instansi yang terait dengan penelitian.

Jumlah pupulasi nelayan gillnet di Desa Sungsang berjumlah 66 nelayan, dan dalam penelitian ini jumlah responden yang penulis wawancarai berjumlah 20 orang.

Metode Analisis: 1) Analisis deskriptif uraian atau usaha untuk mengetahui arti suatu keadaan data atau bahan keterangan mengenai suatu keadaan dan diselidiki hubungannya satu sama lain. Tujuan analisis deskriptif adalah untuk menyederhanakan data-data ke dalam bentuk yang lebih mudah dibaca dan diinterpretasi. Dalam skripsi ini yang akan diamati yaitu antara lain: Jumlah hasil tangkapan nelayan. Harga ikan, kesejahteraaan nelayan berdasarkan data Biro Pusat Statistik Sumatera Selatan.

Analisis usaha dimaksudkan untuk mengetahui kekuatan pengelola secara menyeluruh dalam mengelola kekayaan perusahaan (Hernanto, 1989), maka analisis yang 
digunakan dapat dirincikan sebagai berikut: 1). Analisis R/C Ratio, 2) Analisis Break Event Point (BEP), 3) Analisis Payback Period, 4) Analisis Return On Investment.

Analisis Kriteria Investasi: Analisis ini bertujuan untuk mengetahui apakah suatu usaha layak untuk dikembangkan atau tidak. Menurut Djamin (1993) dalam menghitung analisis ini dapat digunakan analisis sebagai berikut: 1) Net Present Value (NPV), 2) Benefit Cost of Ratio (BCR), 3) Internal Rate Return (IRR)

\section{ANALISIS DATA}

Hasil tangkapan dari 20 responen nelayan gillnet di Sungsang menunjukkan jumlah total tangkapan selama satu tahun yaitu sebanyak $134.400 \mathrm{~kg}$. Dengan demikian rata-rata hasil tangkapan nelayan gillnet di Sungsang sebanyak 6.720kg/tahun. Dengan jumlah hasil tangkapan tertinggi didapatkan oleh nelayan Reza dengan total $7.200 \mathrm{~kg}$ yang menghasilkan pendapatan sebesar Rp 126.000.000/tahun. Sedangkan tangkapan terkecil didapatkan oleh nelayan Rudi dengan hasil tangkapan sebanyak $6.200 \mathrm{~kg}$ dengan penghasilan sebesar Rp 108.500.000/tahun.

Penerimaan usaha nelayan gillnet didapatkan dari hasil kali jumlah hasil tangkapan dikalikan dengan harga rata-rata ikan. Jumlah hasil tangkapan nelayan gillnet sebesar $1.334 .400 \mathrm{~kg} /$ tahun, dengan rata-rata tangkapan sebanyak $6.720 \mathrm{~kg} / \mathrm{nelayan}$. Sehingga penerimaan rata-rata nelayan gillnet setiap tahunnya sebesar Rp 117.600.000.

Nelayan mendapat keuntungan pertahun sebesar Rp 37.037.500 dari total penerimaan dikurangi dengan total biaya. Dengan demikian nelayan mendapatkan rata-rata penghasilan RP 3.086.458/bulan.

Dalam memulai setiap usaha memerlukan investasi. Dalam uasha penangkapan alat tangkap gillnet, nelayan memerlukan investasi yaitu berupa kapal, alat tangkap, dan mesin kapal. Dari 20 responen dalam penelitian ini, mereka menggunakan kapal berukuran 5-30 GT, dengan alat tangkap gillnet yang beragam. Total investasi rata-rata yang dikeluarkan nelayan di Sungsang berjumlah Rp 55.250.000. Jumlah investasi tersebut merupakan jumlah rata-rata yang dikeluarkan nelayan untuk investasi.

Biaya tetap tahunan yang harus dikeluarkan nelayan gillnet antara lain biaya perawatan dan juga penyusutan dari investasi yaitu biaya perawatan kapal sebesar Rp 6.200.000, biaya perawatan mesin kapal sebesar $\mathrm{Rp} 2.350 .000$, biaya perawatan mesin sebesar Rp 2.350.000, biaya perawatan gillnet sebesar $\mathrm{Rp} 1.500 .000$, penyusutan harga kapal sebesar 1.390.000, penyusutan harga mesin Rp 642.500, dan penyusutan harga gillnet sebesar 1.460.000. Jadi total jumlah biaya tetap nelayan gillnet yaitu Rp 13.542.500/tahun.

Selain biaya tetap, dalam usaha alat tangkap gillnet juga terdapat biaya variabel yang berisikan biaya yang harus dikeluarkan nelayan dalam setiap kali melakukan trip penangkapan. Biaya-biaya ini menyangkut biaya solar, oli, es balok, gaji ABK, ransum, dan biaya air bersih. Dengan rincian biaya solar 100L/trip sebesar Rp 952.500 sehingga menjadi Rp 15.240.000/tahun. Biaya oli 10L/trip sebesar Rp 468.750 sehingga menjadi $\mathrm{Rp}$ 7.500.000/tahun. Biaya es balok 10/trip sebesar Rp 314.375 sehingga menjadi $\mathrm{Rp}$ 5.030.000/tahun. Gaji ABK sebanyak 2 orang per trip sebesar Rp 1.260.000 sehingga menjadi Rp 20.160.000/tahun. Biaya Ransum untuk 3 orang sebesar Rp 717.800 menjadi $\mathrm{Rp}$ 11.480.000/tahun. Dan biaya air bersih 100L/trip sebesar Rp 175.625 menjadi 7.610.000. Jadi jumlah biaya variabel yang dikeluarkan untuk setiap trip penangkapan sebesar Rp 4.188.750 dan biaya setiap tahunnya menjadi Rp 67.020.000.

Analisis imbangan peneriman dan biaya adalah hasil bagi anatara penerimaan dan biaya. Analisis imbangan penerimaan dan biaya menunjukkan sejauh mana pengaruh perubahan biaya operasional terhadap penerimaan usaha alat tangkap gillnet. Nilai R-C Ratio pada usaha alat tangkap gillnet adalah sebesar 1,45 angka ini menunjukkan bahwa setiap 
satu rupiah biaya yang dikeluarkan akan menghasilkan penerimaan sebesar Rp 1,45 sehingga dari analisis ini kita melihat bahwa nelayan akan mendapatkan keuntungan.

Analisis ini untuk mengetahui berapa lama waktu yang diperlukan untuk menutupi investasi. Analisis ini dihitung dengan perbandingan nilai investasi berdasarkan keuntungan. Perhitungan PP pada usaha alat tangkap gillnet di Sungsang menunjukkan hasil 1,49 tahun atau sekitar 18 bulan yang berarti investasi

yang ditanam pada usaha alat tangkap gillnet akan kembali setelah jangka waktu 18 bulan.

Cepat lambatnya payback period atau waktu untuk mengembalikan investasi dipengaruhi oleh jumlah hasil tangkapan nelayan dan keuntungan yang didapatkan nelayan. Semakin tinggi hasil tangkapan menyebabkan keuntungan nelayan semakin besar dan akan menyebabkan waktu pengembalian investasi semakin cepat. Sebaliknya, apabila hasil tangkapan dan keuntungan nelayan menurun, maka akan memperlambat waktu pengembalikan investasi.

Analisis ini untuk mengetahui beberapa prosentasi kemungkinan pengembalian keuntungan dari investasi yang ditanamkan dengan asumsi pendapatan setiap bulan atau tahun tetap. Nilai ROI untuk usaha alat tangkap gillnet dari investasi yang ditanamkan yaitu sekitar 27\% pada usaha alat tangkap gillnet di Sungsang.

Yang mempengaruhi return of investmen yaitu nilai laba usaha dan modal usaha. Semakin besar keuntungan maka nilai ROI akan semakin besar. Dalam perhitungan ini didapatkan ROI sebesar $27 \%$ yang menandakan bahwa keuntungan setiap tahun yang didapatkan nelayan gillnet sebesar $27 \%$ dari jumlah modalusaha yang nelayan keluarkan.

Analisis kriteria investasi dilakukan untuk menentukan layat atau tidaknya suatu usaha untuk dilakukan. Nilai Net Present Value untuk usaha penangkapan ikan dengan alat tangkap gillnet di Sungsang sebesar Rp 69.196.000. Perhitungan nilai NPV pada usaha ini menandakan bahwa adanya penambahan nilai menjadi Rp 69.196.000. Hal ini menunjukkan NPV $>0$, sehingga usaha ini layak untuk dijalankan.

Nilai Net Benefit Cost Ratio untuk usaha penangkapan ikan dengan alat tangkap gillnet di Sungsang sebesar 1.28. Nilai tersebut menyatakan bahwa Net B/C

$\geq 1$, usaha penangkapan ikan dengna alat tangkap gillnet di Sungsang layak untuk dijalankan.

Hasil nilai net benefit cost ratio yang sebesar 1,28 ini menandakan bahwa total benefit atau keuntungan dari usaha ini yaitu sebanyak 1.28 kali dari total biaya yang dikeluarkan nelayan.

Nilai IRR untuk penangkapan ikan dengan alat tangkap gillnet di Sungsang sebesar 19,46\%. Nilai ini lebih besar dari pada nilai suku bunga sebesar 15\% selama satu tahun, dengan demikian usaha penangkapan ikan dengan alat tangkap gillnet layak untuk dijalankan karena tergolong usaha yang menguntungkan.

\section{KESIMPULAN DAN SARAN}

Hasil dari pengamatan dan analisis usaha penangkapan ikan dengan alat tangkap gillnet di Sungsang telah penulis lakukan dan dapat disimpulkan sebagai berikut:

1). Berdasarkan perhitungan penerimaan usaha alat tangkap gillnet dalam waktu satu tahun mendapatkan hasil sebesar Rp 117.600.000 dari jumlah hasil tangkapan dikalikan dengan harga jual ikan. Nelayan mendapat keuntungan pertahun sebesar Rp 37.037.500 dari total penerimaan dikurangi dengan total biaya. Dengan demikian nelayan mendapatkan rata-rata penghasilan RP 3.086.458/bulan.

2) Hasil analisis usaha kriteria investasi dengan cara menghitung nilai NPV. Net

B/C dan IRR yang akan menunjukkan usaha alat tangkap gillnet layak untuk dijalankan. Dari niali NPV pada tahun ke 5 mendapatkan hasil Rp 69.196.000. Nilai Net 
$\mathrm{B} / \mathrm{C}$ bernilai 1.28 hal ini menunjukkan kontribusi manfaat bersih terhadap biaya selama umur usaha 5 tahun dengan tingkat usku bunga 15\%. Berdasarkan perhitungan nilai IRR pada tingkat suku bunga $15 \%$ yang menyebabkan nilai NPV bernilai nol pada tingkat suku bunga sebesar 19,46\%.

Saran pada penelitian ini pada usaha alat tangkap gillnet di Sungsang perlu dikembangkan kembali, serta peran dari instansi pemerintahan mengenai perkembangan perikanan tangkap serta infrastruktur di Sungsang perlu diperhatikan lagi, karena dilihat dari segi analisis usaha penangkapan ikan dengan gillnet juga turut membantu perekonomian nelayan tradisional di Sungsang.

\section{DAFTAR PUSTAKA}

Hernanto F. 1989. Ilmu Usaha Tani. Cetakan ke-7. Jakarta: Penebar Swadaya. Rahardi, R. Kristiawati dan Nazarudin. 1993. Agribisnis Perikanan. Jakarta: Penebar Swadaya 